\title{
Severe growth hormone deficiency is rare in surgically-cured acromegalics
}

\author{
Shingo Fujio - Hiroshi Tokimura $\cdot$ Hirofumi Hirano $\cdot$ Ryosuke Hanaya \\ Fumikatsu Kubo · Shunji Yunoue - Manoj Bohara • Yasuyuki Kinoshita • \\ Atsushi Tominaga $\cdot$ Hiroshi Arimura $\cdot$ Kazunori Arita
}

Published online: 24 August 2012

(C) The Author(s) 2012. This article is published with open access at Springerlink.com

\begin{abstract}
Growth hormone deficiency (GHD) in surgically-cured acromegalics has been reported to negatively affect their metabolic condition and quality of life (QOL). The incidence of GHD, its causes, and its effects on their physio-psychological condition remain to be examined in detail. We performed a retrospective study to investigate GH secretory function in surgically-cured acromegalics, prognostic factors of GHD, and its impact on QOL. The study population consisted of 72 acromegalics who were determined to be surgically cured according to the Cortina consensus criteria. We recorded the incidence of impaired GH secretory function based on the peak GH level during postoperative insulin tolerance test (ITT) which lowered their nadir blood sugar to under $50 \mathrm{mg} / \mathrm{dL}$. Their QOL was evaluated by SF-36. In surgically-cured acromegalics, the incidence of severe GHD (peak GH during ITT $\leqq 3.0 \mu \mathrm{g} / \mathrm{L}$ ) was $12.5 \%$ (9/72). The preoperative tumor size was significantly larger in patients with severe GHD than without severe GHD $(21.9 \pm 9.0$ vs. $15.5 \pm 7.1 \mathrm{~mm}, p=0.017)$. The peak GH levels during postoperative ITT were
\end{abstract}

S. Fujio $\cdot$ H. Tokimura $\cdot$ H. Hirano $(\bowtie) \cdot$ R. Hanaya

F. Kubo $\cdot$ S. Yunoue $\cdot$ M. Bohara $\cdot$ K. Arita

Department of Neurosurgery, Graduate School of Medical and Dental Sciences, Kagoshima University, 8-35-1,

Sakuragaoka, Kagoshima 890-8520, Japan

e-mail: hirahira@m2.kufm.kagoshima-u.ac.jp

Y. Kinoshita $\cdot$ A. Tominaga

Department of Neurosurgery, Graduate School of Biomedical

Science, Hiroshima University, 1-2-3, Kasumi,

Minami-ku, Hiroshima 734-8551, Japan

H. Arimura

Department of Diabetes and Endocrinology, Graduate School

of Medical and Dental Sciences, Kagoshima University,

8-35-1, Sakuragaoka, Kagoshima 890-8520, Japan statistically correlated with the physical but not the mental component summary of the SF-36 score. The incidence of GHD was $12.5 \%$ in our surgically-cured acromegalics. As some QOL aspects are positively related with peak GH levels during postoperative ITT, efforts should be made to preserve pituitary function in acromegalic patients undergoing adenomectomy.

Keywords Acromegaly - Growth hormone deficiency · Surgery $\cdot$ Pituitary function

\section{Introduction}

Acromegaly leads to serious metabolic disruptions and intercurrent illnesses, negatively affects the patients' quality of life (QOL), and increases their mortality rates. Good control of the disease improves their metabolic condition, lessens their morbidity, and raises their life expectancy to that of unaffected individuals [1-3]. Treatments include transsphenoidal surgery under microscopic and/or endoscopic observation, dopamine receptor agonists, somatostatin analogues, $\mathrm{GH}$ receptor antagonists, and stereotactic radiation. Due to the introduction of endoscopic surgery and advances in surgical techniques, the surgical cure rate is $60-70 \%$ [4-6].

Growth hormone (GH) affects not only the metabolism and organs but also the mental health of adults and children. And GH deficiency (GHD) disturbs the metabolic condition, lowers QOL, and may lead to premature death due to cardiovascular diseases. Appropriate GH replacement therapy reverses these effects $[7,8]$. So the prime treatment goal in patients with acromegaly should be not only the correction of hypersomatotropinemia by eradication of the GH-producing adenoma but also maintenance of 
the secretory function of $\mathrm{GH}$ from the pituitary gland. However, in $40-70 \%$ of acromegalics, GH secretory function has been reported to be impaired postoperatively [9-11]; their metabolic condition is adversely affected and their QOL is decreased [12]. While, Yamada et al. [13] very recently reported a low rate of GHD in patients treated by surgery alone.

We performed a retrospective study on acromegalics treated by selective adenomectomy. They underwent insulin tolerance tests (ITT) 3-12 months after the operation to assess GH secretory function. We also assessed the postoperative secretory function of their other anterior pituitary hormones and QOL. Additionally, their postoperative GH secretory function was compared with that of the patients with clinically nonfunctioning pituitary adenomas treated by total or subtotal adenomectomy.

\section{Patients and methods}

\section{Subjects}

From 1999 through 2011, 136 acromegalics underwent endonasal-transsphenoidal surgery performed or supervised by a senior neurosurgeon (K.A.). All operations were under a microscope and most were aided by endoscopic observation. Surgical cure, judged by Cortina Consensus criteria, i.e. a nadir GH level during the postoperative oral glucose tolerance test (OGTt) $<1 \mu \mathrm{g} / \mathrm{L}$ and a normal IGF-1 level, was achieved in 92 of the 136 patients $(67.6 \%)$. No patient developed permanent postoperative diabetes insipidus or cranial nerve impairment. We were able to assess postoperative GH secretory function in 89 patients; in 79 this was performed with the ITT and in 10 we used the arginine test because their age and/or persistent hyperglycemia made use of the ITT inadvisable. As the nadir blood glucose level exceeded $50 \mathrm{mg} / \mathrm{dL}$ in 7 of the 79 patients who underwent ITT, they were excluded from this study.

The final study population was thus comprised of 72 surgically-cured acromegalics, 25 males and 47 females with age ranging $18-71$ years $(50.8 \pm 12.3$, mean $\pm \mathrm{SD})$. Their body mass index (BMI) was 17.2-34.9 (24.0 \pm 3.4$)$. GH level ranged from 1.55 to $238.6 \mu \mathrm{g} / \mathrm{L}(21.12 \pm 32.7 \mu \mathrm{g} / \mathrm{L})$ and IGF-1 level from 170.3 to $1947.6 \mu \mathrm{g} / \mathrm{L}(812.0 \pm 375.0 \mu \mathrm{g} / \mathrm{L})$. The tumor size ranged from 5 to $41 \mathrm{~mm}(16.3 \pm 7.6 \mathrm{~mm})$. The mean nadir GH level during postoperative glucose tolerance test was $0.28 \pm 0.22 \mu \mathrm{g} / \mathrm{L}$.

\section{Methods}

For ITT we intravenously injected $0.1-0.15$ unit $/ \mathrm{kg}$ insulin in the morning. The delivered insulin dose was based on the fasting glucose level. Peripheral blood was drawn to measure the level of glucose, $\mathrm{GH}$, adrenocorticotropic hormone (ACTH), and cortisol at 0-, 30-, 60-, and 90-min post-injection. The patient's condition was closely monitored and if the blood glucose level fell below $25 \mathrm{mg} / \mathrm{dL}$ it was adjusted with a $20 \%$ glucose solution.

The patients' GH secretory status was categorized according to the peak $\mathrm{GH}$ level during the test, where peak $\mathrm{GH}>6.0 \mu \mathrm{g} / \mathrm{L}=$ normal, $3.0<$ peak $\mathrm{GH} \leqq 6.0 \mu \mathrm{g} / \mathrm{L}=$ slightly impaired, and peak $\mathrm{GH} \leqq 3.0 \mu \mathrm{g} / \mathrm{L}=$ severe GHD.

In order to assess the function of other pituitary hormones, we also performed luteinizing hormone-releasing hormone (LHRH) and thyrotropin-releasing hormone (TRH) tests and measured target hormones of anterior pituitary hormones on other mornings during a period of 3-6 months after surgery. The determination of hormonal impairment was basically based on a criteria reported by Melmed and Kleinberg [14].

In 43 patients we measured the GH concentration by electro-chemiluminescence-immunoassay (ECL) (Immulite 2000 hGH, Siemens, Erlangen, Germany) using recombinant human GH as the standard. The sensitivity of this assay was $0.1 \mu \mathrm{g} / \mathrm{L}$. In 29 patients whose $\mathrm{GH}$ level was determined by immunoradiometric assay (IRMA) before the introduction of recombinant $\mathrm{GH}$ as the standard in 2005, the obtained GH values were converted into ECL GH values using the formula $\mathrm{ECL}$ GH value $=0.6 \times$ IRMA GH value. The IGF1 concentration was measured by IRMA (IGF-1 IRMA "Daiichi", TFB, Tokyo, Japan) in 27 patients and with the Somatomedin C II Bayer kit (Yuka Medias Co. Ltd., Ibaragi, Japan) in 45 patients. The raw IGF-1 values were assessed according to IGF-1 standard deviation scores (IGF-1-SDscores) calculated based on the standard IGF-1 values of each gender and age group in the Japanese population [15].

The patients' QOL was evaluated using SF-36 (ver. 2) questionnaire and presented as relative scores standardized with Japanese general population; the standard value was set at 50 .

For comparison we assessed postoperative GH secretory function in 99 patients with clinically nonfunctioning adenomas who underwent total or gross total removal during the same period. They were 49 males and 50 females ranging in age from 14 to 71 years (mean $51.5 \pm 12.5$ years). Their tumor size ranged from 11 to $52 \mathrm{~mm}$ (mean $28.4 \pm 8.8 \mathrm{~mm}$ ).

Statistical analysis

The Statflex software program (version 6.0) was used for statistical analysis of the results. Depending on the characteristics of the data sets, data were analyzed with Fisher's exact test, the Mann-Whitney $U$ test, Student's $t$ test, or a simple correlation test. Differences of $p<0.05$ were considered statistically significant. 
Ethical considerations

This retrospective study was approved by the Ethics Committee of Kagoshima University Hospital (reference No. 18-53 and No. 20-144). All investigated data were acquired in a routine fashion and were essential for the proper management of the patients with pituitary disease. To protect patient privacy all data were analyzed under anonymization in a linkable fashion.

\section{Results}

Prevalence of GH impairment

The incidence of postoperatively impaired GH secretory function was $12.5 \%(9 / 72)$ in patients with severe GHD (peak GH during ITT $\leqq 3 \mu \mathrm{g} / \mathrm{L}$ ) and $15.3 \%$ (11/72) in patients with slightly impaired GH secretory function (3.0 $\mu \mathrm{g} / \mathrm{L}<$ peak $\mathrm{GH} \leqq 6.0 \mu \mathrm{g} / \mathrm{L}) \quad$ (Figs. 1, 2). In 52 patients $(72.2 \%) \mathrm{GH}$ secretory function was preserved; their peak $\mathrm{GH}$ exceeded $6 \mu \mathrm{g} / \mathrm{L}$.

When we set $16 \mathrm{~mm}$ as the cut-off, mean of all the tumor sizes, $25.9 \%$ of patients with tumors larger than $16 \mathrm{~mm}$ and $4.4 \%$ of patients with tumors smaller than $16 \mathrm{~mm}$ had severe GHD ( $p=0.01$, Fisher's exact test). The median IGF-1-SD-score of 9 patients with severe GHD was 0.82 with mean of $0.38 \pm 0.95$ (SD) (Fig. 3). IGF-1SD-score tended to correlate with the peak GH concentration during ITT although the association was not significant ( $p=0.14$ ) (Fig. 4).

The postoperative incidence of severe GHD in patients with nonfunctioning pituitary adenomas was as high as $46.5 \%$. The median of IGF-1-SD-score of 46 patients with nonfunctioning pituitary adenomas and postoperative severe GHD was -1.44 with mean of $-1.43 \pm 1.36$ (SD) (Fig. 3).

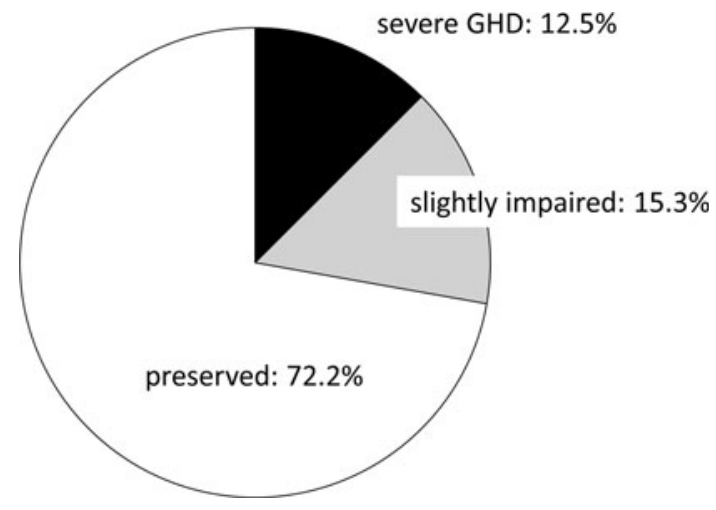

Fig. 2 Postoperative status of GH secretory function in 72 surgically cured acromegalics. The incidence of severe GHD was $12.5 \%$

We judged anterior pituitary hormonal functions as intact when the test results met the following criteria. For ACTH-cortisol; the peak cortisol level was $>15 \mu \mathrm{g} / \mathrm{dL}$. For TSH; normal levels of TSH $(0.5-5.0 \mu \mathrm{IU} / \mathrm{mL})$ and FT4 $(>1.1 \mathrm{ng} / \mathrm{dL})$ and the peak TSH level was $>2.5$ times the basal level. For prolactin; the peak prolactin level was $>20 \mu \mathrm{g} / \mathrm{L}$ and 2.5 times the basal level. For gonadotropin for female: menstrual state-appropriate estradiol level and peak LH level was $>15 \mathrm{mIU} / \mathrm{mL}$ and 2 times the basal level. For gonadotropin for male: normal testosterone level $(>2 \mathrm{ng} / \mathrm{mL})$ and peak $\mathrm{LH}$ level was $>15 \mathrm{mIU} / \mathrm{mL}$ or 2 times the basal level. The impairment rate was $8.3 \%$ for the ACTH-cortisol axis, $9.7 \%$ for TSH, $23.6 \%$ for gonadotropin, $6.9 \%$ for prolactin, respectively.

Clinical and endocrinologic data on patients with and without severe GHD are presented in Table 1. The tumor size was significantly larger in the severe GHD group (peak $\mathrm{GH} \leqq 3 \mu \mathrm{g} / \mathrm{L})$ than the non-severe GHD group (21.9 \pm 9.0 vs. $15.5 \pm 7.1 \mathrm{~mm}, p=0.017$, Mann-Whitney $U$ test). Other clinical features including the patients' age, sex, and
Fig. 1 Changes in growth hormone $(\mathrm{GH})$ levels during the postoperative insulin tolerance test (ITT) in 72 surgically cured acromegalics. From left to right; 9 patients with severe growth hormone deficiency (GHD), 11 with slightly impaired-, and 52 with normal GH secretion. Bars indicate the standard deviation (SD)

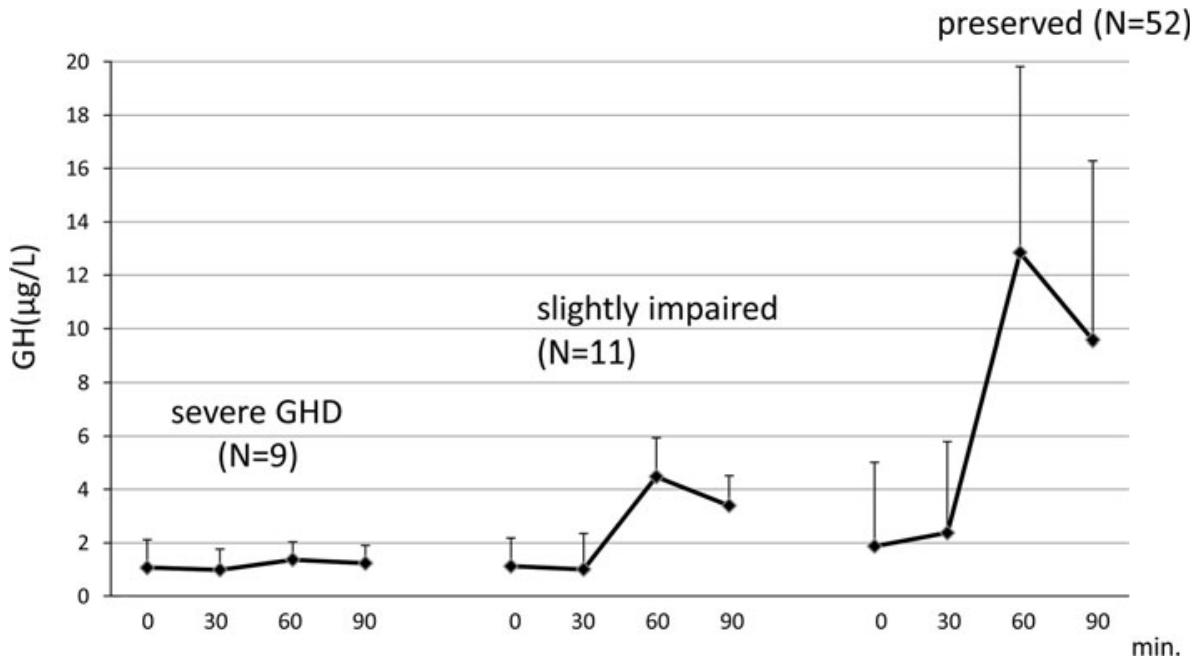




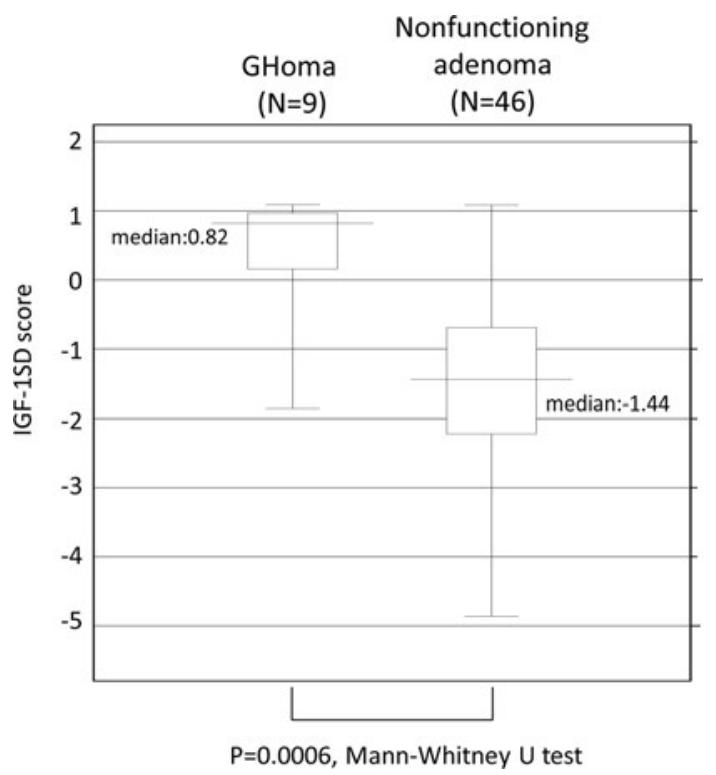

Fig. 3 Box plots of the IGF-1-SD-scores of severe GHD patients. Left column surgically cured acromegalics $(\mathrm{n}=9)$. Right column patients with totally or subtotally removed nonfunctioning pituitary adenomas $(n=46)$. The difference is statistically significant $(p<0.001$, Mann-Whitney)

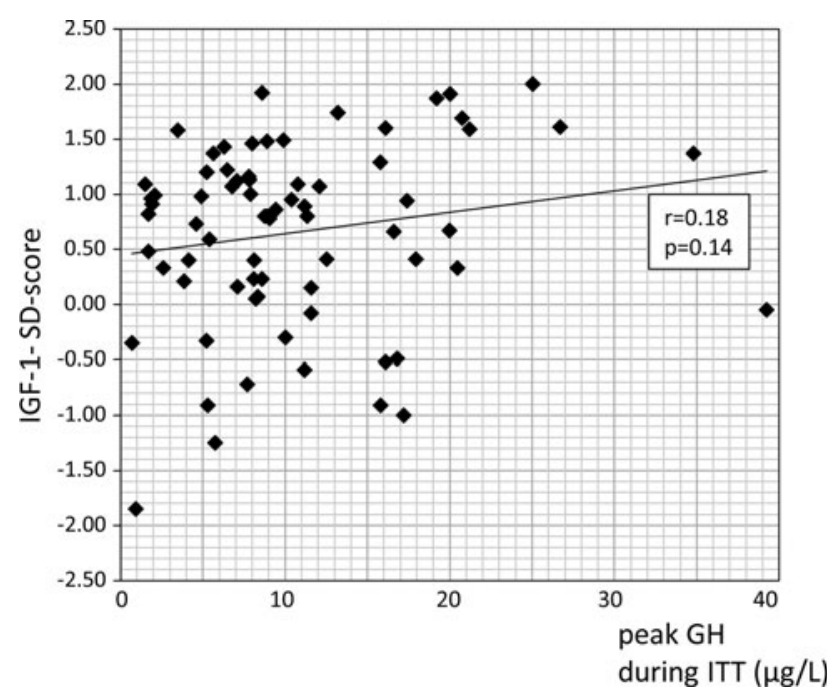

Fig. 4 Relationship between the peak GH concentration and the IGF1 -SD-score during postoperative ITT in surgically cure acromegalics

their pre- and post-operative GH and IGF-1 level did not affect the tendency for severe GHD.

We did not find a difference in the SF-36 scores between patients with $(n=9)$ and without $(n=63)$ severe GHD. On the other hand, the peak GH level correlated statistically with the physical component summary of SF-36 $(\mathrm{r}=0.31, p=0.016$, Fig. 5) but not with its mental component.
Table 1 Clinical and endocrinologic status in 9 patients with severe growth hormone deficiency (GHD) and 63 without severe GHD

\begin{tabular}{|c|c|c|c|}
\hline & Severe GHD & $\begin{array}{l}\text { Non-severe } \\
\text { GHD }\end{array}$ & $p$ value \\
\hline Number of cases & 9 & 63 & \\
\hline \multicolumn{4}{|l|}{ Preoperative characteristics } \\
\hline Ages(years) & $54.8 \pm 9.3$ & $50.3 \pm 12.3$ & $0.38^{\mathrm{a}}$ \\
\hline Sex(male/female) & $1 / 8$ & $24 / 39$ & $0.15^{\mathrm{b}}$ \\
\hline BMI & $23.2 \pm 2.6$ & $24.1 \pm 3.5$ & $0.48^{\mathrm{a}}$ \\
\hline Preoperative GH levels & $48.6 \pm 77.2$ & $17.2 \pm 18.2$ & $0.59^{\mathrm{a}}$ \\
\hline $\begin{array}{l}\text { Preoperative IGF-1 } \\
\text { levels }\end{array}$ & $826.9 \pm 354.8$ & $809.9 \pm 380.5$ & $0.78^{\mathrm{a}}$ \\
\hline IGF-1-SD-score & $7.76 \pm 2.4$ & $7.44 \pm 2.74$ & $0.62^{\mathrm{a}}$ \\
\hline Tumor sizes & $21.9 \pm 9.0$ & $15.5 \pm 7.1$ & $0.017^{\mathrm{a}}$ \\
\hline \multicolumn{4}{|l|}{ Follows-up results } \\
\hline $\begin{array}{l}\text { Nadir GH levels on } \\
75 \mathrm{~g} \text { OGTt }\end{array}$ & $0.32 \pm 0.26$ & $0.27 \pm 0.22$ & $0.63^{\mathrm{a}}$ \\
\hline IGF-1 levels & $160.9 \pm 47.0$ & $218.9 \pm 87.4$ & $0.055^{\mathrm{a}}$ \\
\hline IGF-1-SD-score & $0.38 \pm 0.95$ & $0.70 \pm 0.81$ & $0.37^{\mathrm{a}}$ \\
\hline
\end{tabular}

SDS Standard deviation score, $S D$ standard deviation

a Mann-Whitney $U$ test

${ }^{\mathrm{b}}$ Fisher's exact test

\section{Discussion}

It has been shown that $30-70 \%$ of acromegalics develop GHD after radiotherapy [9, 16-18]. Although there was a report that surgical treatment without radiation rarely caused GHD[16], high incidences, more than $50 \%$, of GHD in surgically cured acromegalics were reported [9, 12]. The incidence of severe GHD in surgically-cured Japanese acromegalics was $9.1 \%$; their postoperative GH secretory function was evaluated by GHRP-2 test [13]. The rate of severe GHD was also low, $12.5 \%$, in our patients with surgically cured acromegalics whose GH secretory function was determined by ITT. Differences in the reported rates of severe GHD may be attributable to difference in the study population, the tumor size, the methods used to evaluate $\mathrm{GH}$ secretory function, the interval after completion of treatments, the metabolic background, and the manipulation of the pituitary gland during surgery.

In a series reported by Ronchi et al. [9] in 2009, 18 of 33 $(54.5 \%)$ patients treated by surgery alone manifested severe GHD. Among 45 cured acromegalics studied by Wexler et al. [12], including 26 who underwent postoperative radiation therapy, 26 (57.8 \%) were GH deficient. Considering these results were reported from large volume centers, the number of patients selected for the assessment of post-treatment $\mathrm{GH}$ secretory function may be a small part of actual number of acromegalics treated at the institutions.

On the other hand, Yamada et al. [13] included all operated patients who were regularly followed between 
Fig. 5 Relationship between the peak GH concentration and the physical (a) and mentalcomponent scores (b) of SF-36 in surgically-cured acromegalics. The physical component scores correlated positively with the peak $\mathrm{GH}$ concentration during ITT ( $\mathrm{r}=0.31, p=0.016$, simple correlation test)

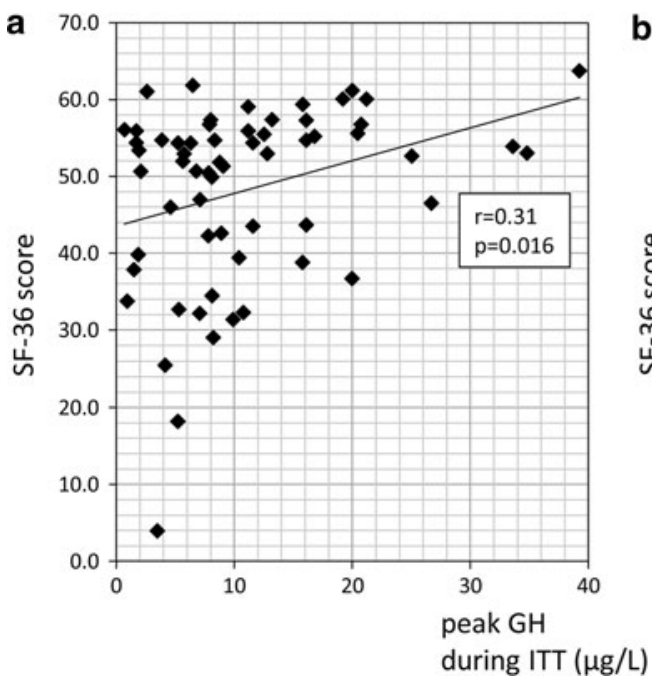

2009 and 2010 and our study population was comprised of almost all surgically-cured patients who underwent ITT between 1999 and 2011. Therefore, the low incidence of GHD in the series of Yamada et al. and ours may better reflect the actual status of GH secretory function in surgically-cured acromegalics.

In our series, as in patients reported by Ronchi et al. [9], the only prognostic factor for severe GHD was the preoperative size of the adenomas. This suggests that the impairment of GH secretory function began before surgery due to the compression of the pituitary gland and/or pituitary stalk by large tumors. The incidence of severe GHD was $46.5 \%$ in patients who underwent total or subtotal removal of nonfunctioning adenomas in our series. According to Greenman et al. [19], 17 and $68 \%$ of operated patients with somatotropinomas and nonfunctioning adenomas, respectively, manifested pituitary deficiency. As the tumor size was a prognostic factor for GHD and as there was a big difference between somatotropinomas and nonfunctioning pituitary adenomas (mean size 16.3 vs. $28.4 \mathrm{~mm}$ ), the incidence of severe GHD in surgically-cured acromegalics can be expected to be much lower than that in patients with nonfunctioning pituitary adenomas, which actually was 12.5 and $46.5 \%$, respectively in our series.

The optimal timing for the postoperative evaluation and the ideal time to start hormone replacement therapy in patients with GHD remain to be identified. We performed ITT $189.9 \pm 188.1$ (mean \pm SD) days after surgery. In some studies pituitary function recovered over time [20, 21]. Ronchi et al. [9] reported a negative correlation between peak GH and the duration of follow-up after the first treatment. Their observation must be confirmed by follow-up studies of a fixed group of patients.

The low incidence of GHD in Japanese patients may be attributable to a low obesity rate; the body mass index (BMI) in our patients was $24.0 \pm 3.4(\mathrm{SD})$, lower than that in non-Japanese reported by others [9, 22-24]. In obese patients GH release is depressed, as are 24-h GH secretion, and the responsiveness to provocation tests [25-28].

The low incidence of GHD may also be related to the growth direction of somatotropinomas; they very often grow inferiorly without dislocation or compression of the pituitary gland $[29,30]$. Thus, preservation of GH secretory function may be attributable to the anatomical conservation of the pituitary gland in patients with these tumors.

Growth hormone deficiency has adverse effects on the QOL [7, 8, 31-33] which is the case in cured acromegalics $[12,34]$. In our series, the peak GH value during ITT correlated with the physical but not the mental component of SF-36. Strong correlation of QOL to peak GH during GH provocation test was also reported by Wexler et al. [12]. But, we found no difference in the SF-36 scores of 9 patients with severe GHD and 63 without severe GHD, reasons remain to be elucidated. We posit that the incorrect belief of being perfectly healthy due to successful surgery in some surgically-cured acromegalics may have brought about excessively high postoperative QOL scores and cancelled the difference between two groups. Actually, in our 26 acromegalic patients whose pre- and post-operative QOL were evaluated, the mental components summary of SF-36 were $46.7 \pm 12.6$ and $51.4 \pm 8.9$, respectively; the standard value was set at $50(p=0.049)$.

Another factor to explain the lack of difference of QOL between severe GHD and non-severe GHD groups may be the relatively well-maintained IGF-1 level in acromegalics manifesting severe GHD. The mean IGF-1-SD-score in 9 cured acromegalics with severe GHD in our series was significantly higher than in cured patients with nonfunctioning adenomas who had severe GHD $(0.38 \pm 0.95$ vs. $-1.43 \pm 1.36$, Fig. 3). A similar observation was made by Ronchi et al. [9]; cured acromegalics with GHD had a higher IGF-1-SD-score than did GHD patients treated for other pituitary diseases. 
Thus, mild GH excess and/or GH dysregulation may exist in surgically-cured acromegalics and may account for their relatively maintained IGF-1 level in the presence of severe GHD and may contribute to the maintenance of some QOL components.

In conclusion, we report that a small proportion of surgically-cured acromegalics fulfilled the criteria for severe GHD and that the physical aspect of their SF-36 scores correlated positively with the peak GH level in the ITT. The preoperative tumor size was a predictive factor for postoperative severe GHD. Considering the reported longitudinal changes in GH secretory function in cured acromegalics, future studies should include serial examination during long term follow-up.

Acknowledgments This work was supported (in part) by Grants-in-Aid for Scientific Research (Research on Hypothalamo-Pituitary Dysfunction) from the Japanese Ministry of Health, Labor and Welfare and National Cancer Center Research and Development Fund (grant number 21-8-6: Diagnosis and Treatment of Intractable Endocrine Tumors by principle investigator, Dr. Akira Shimatsu).

Open Access This article is distributed under the terms of the Creative Commons Attribution License which permits any use, distribution, and reproduction in any medium, provided the original author(s) and the source are credited.

\section{References}

1. Holdaway IM, Rajasoorya RC, Gamble GD (2004) Factors influencing mortality in acromegaly. J Clin Endocrinol Metab 89: 667-674

2. Arita K, Kurisu K, Tominaga A, Eguchi K, Iida K, Uozumi T, Kasagi F (2003) Mortality in 154 surgically treated patients with acromegaly - a 10-year follow-up survey. Endocr J 50:163-172

3. Beauregard C, Truong U, Hardy J, Serri O (2003) Long-term outcome and mortality after transsphenoidal adenomectomy for acromegaly. Clin Endocrinol (Oxf) 58:86-91

4. Jane JA Jr, Starke RM, Elzoghby MA, Reames DL, Payne SC, Thorner MO, Marshall JC, Laws ER Jr, Vance ML (2011) Endoscopic transsphenoidal surgery for acromegaly: remission using modern criteria, complications, and predictors of outcome. J Clin Endocrinol Metab 96:2732-2740

5. Gondim JA, Almeida JP, de Albuquerque LA, Gomes E, Schops M, Ferraz T (2010) Pure endoscopic transsphenoidal surgery for treatment of acromegaly: results of 67 cases treated in a pituitary center. Neurosurg Focus 29:E7

6. Campbell PG, Kenning E, Andrews DW, Yadla S, Rosen M, Evans JJ (2010) Outcomes after a purely endoscopic transsphenoidal resection of growth hormone-secreting pituitary adenomas. Neurosurg Focus 29:E5

7. Monson JP (2003) Long-term experience with GH replacement therapy: efficacy and safety. Eur J Endocrinol 148:S9-S14

8. Verhelst J, Abs R (2002) Long-term growth hormone replacement therapy in hypopituitary adults. Drugs 62:2399-2412

9. Ronchi CL, Giavoli C, Ferrante E, Verrua E, Bergamaschi S, Ferrari DI, Corbetta S, Montefusco L, Arosio M, Ambrosi B, Spada A, Beck-Peccoz P (2009) Prevalence of GH deficiency in cured acromegalic patients: impact of different previous treatments. Eur J Endocrinol 161:37-42
10. Conceição FL, Fisker S, Andersen M, Kaal A, Jørgensen JO, Vaisman M, Christiansen JS (2003) Evaluation of growth hormone stimulation tests in cured acromegalic patients. Growth Horm IGF Res 13:347-352

11. Pekic S, Doknic M, Miljic D, Joksimovic M, Glodic J, Djurovic M, Dieguez C, Casanueva F, Popovic V (2006) Ghrelin test for the assessment of GH status in successfully treated patients with acromegaly. Eur J Endocrinol 154:659-666

12. Wexler T, Gunnell L, Omer Z, Kuhlthau K, Beauregard C, Graham G, Utz AL, Biller B, Nachtigall L, Loeffler J, Swearingen B, Klibanski A, Miller KK (2009) Growth hormone deficiency is associated with decreased quality of life in patients with prior acromegaly. J Clin Endocrinol Metab 94:2471-2477

13. Yamada S, Fukuhara N, Nishioka H, Takeshita A, Suzuki H, Miyakawa M, Takeuchi Y (2011) GH deficiency in patients after cure of acromegaly by surgery alone. Eur $\mathrm{J}$ Endocrinol 165:873-879

14. Melmed S, Kleinberg D (2008) Anterior pituitary. In: Kronenberg HM, Melmed S, Polonsky KS, Larsen PR (eds) William's textbook of endocrinology, 11th edn. Elsevier, Amsterdam, pp 238-242

15. Isojima T, Shimatsu A, Yokoya S, Chihara K, Tanaka T, Hizuka N, Teramoto A, Tatsumi KI, Tachibana K, Katsumata N, Horikawa R (2012) Standardized centile curves and reference intervals of serum insulin-like growth factor-I (IGF-I) levels in a normal Japanese population using the LMS method. Endocr J. doi:DN/JST.JSTAGE/endocrj/EJ12-0110

16. Murray RD, Peacey SR, Rahim A, Toogood AA, Thorner MO, Shalet SM (2001) The diagnosis of growth hormone deficiency (GHD) in successfully treated acromegalic patients. Clin Endocrinol 54:37-44

17. Biermasz NR, van Dulken H, Roelfsema F (2000) Long-term follow-up results of postoperative radiotherapy in 36 patients with acromegaly. J Clin Endocrinol Metab 85:2476-2482

18. van der Klaauw AA, Pereira AM, van Thiel SW, Smit JW, Corssmit EP, Biermasz NR, Frolich M, Iranmanesh A, Veldhuis JD, Roelfsema F, Romijn JA (2006) GH deficiency in patients irradiated for acromegaly: significance of GH stimulatory tests in relation to the $24 \mathrm{~h} \mathrm{GH}$ secretion. Eur J Endocrinol 154:851-858

19. Greenman Y, Tordjman K, Kisch E, Razon N, Ouaknine G, Stern N (1995) Relative sparing of anterior pituitary function in patients with growth hormone-secreting macroadenomas: comparison with nonfunctioning macroadenomas. J Clin Endocrinol Metab 80:1577-1583

20. Arafah BM, Kailani SH, Nekl KE, Gold RS, Selman WR (1994) Immediate recovery of pituitary function after transsphenoidal resection of pituitary macroadenomas. J Clin Endocrinol Metab 79:348-354

21. Berg C, Meinel T, Lahner H, Mann K, Petersenn S (2010) Recovery of pituitary function in the late-postoperative phase after pituitary surgery: results of dynamic testing in patients with pituitary disease by insulin tolerance test 3 and 12 months after surgery. Eur J Endocrinol 162:853-859

22. Sardella C, Lombardi M, Rossi G, Cosci C, Brogioni S, Scattina I, Webb SM, Gasperi M, Martino E, Bogazzi F (2010) Short- and long-term changes of quality of life in patients with acromegaly: results from a prospective study. J Endocrinol Invest 33:20-25

23. Sze L, Schmid C, Bloch KE, Bernays R, Brändle M (2007) Effect of transsphenoidal surgery on sleep apnoea in acromegaly. Eur $\mathrm{J}$ Endocrinol 156:321-329

24. Delaroudis SP, Efstathiadou ZA, Koukoulis GN, Kita MD, Farmakiotis D, Dara OG, Goulis DG, Makedou A, Makris P, Slavakis A, Avramides AI (2008) Amelioration of cardiovascular risk factors with partial biochemical control of acromegaly. Clin Endocrinol (Oxf) 69:279-284

25. Biller BM, Samuels MH, Zagar A, Cook DM, Arafah BM, Bonert V, Stavrou S, Kleinberg DL, Chipman JJ, Hartman ML (2002) 
Sensitivity and specificity of six tests for the diagnosis of adult GH deficiency. J Clin Endocrinol Metab 87:2067-2079

26. Veldhuis JD, Iranmanesh A, Ho KK, Waters MJ, Johnson ML, Lizarralde G (1991) Dual defects in pulsatile growth hormone secretion and clearance subserve the hyposomatotropism of obesity in man. J Clin Endocrinol Metab 72:51-59

27. Vizner B, Reiner Z, Sekso M (1983) Effect of L-dopa on growth hormone, glucose, insulin, and cortisol response in obese subjects. Exp Clin Endocrinol 81:41-48

28. Hartman ML (2000) Physiological regulators of growth hormone secretion. In: Juul A, Jørgensen JOL (eds) Growth hormone in adults, 2nd edn. Cambridge University Press, Cambridge, pp 3-53

29. Hagiwara A, Inoue $Y$, Wakasa K, Haba T, Tashiro T, Miyamoto T (2003) Comparison of growth hormone-producing and nongrowth hormone-producing pituitary adenomas: imaging characteristics and pathologic correlation. Radiology 228:533-538

30. Zada G, Lin N, Laws ER Jr (2010) Patterns of extrasellar extension in growth hormone-secreting and nonfunctional pituitary macroadenomas. Neurosurg Focus 29:E4

31. Shimatsu A, Tai S, Tanaka T, Fujieda K, Teramoto A, Chihara K (2011) Clinical characteristics of Japanese adults with growth hormone deficiency: a HypoCCS database study. Endocr J 58: 325-333

32. Attanasio AF, Lamberts SW, Matranga AM, Birkett MA, Bates PC, Valk NK, Hilsted J, Bengtsson BA, Strasburger CJ (1997) Adult growth hormone $(\mathrm{GH})$-deficient patients demonstrate heterogeneity between childhood onset and adult onset before and during human GH treatment. Adult Growth Hormone Deficiency Study Group. J Clin Endocrinol Metab 82:82-88

33. Burman P, Broman JE, Hetta J, Wiklund I, Erfurth EM, Hagg E, Karlsson FA (1995) Quality of life in adults with growth hormone (GH) deficiency: response to treatment with recombinant human $\mathrm{GH}$ in a placebo-controlled 21-month trial. J Clin Endocrinol Metab 80:3585-3590

34. Miller KK, Wexler T, Fazeli P, Gunnell L, Graham GJ, Beauregard C, Hemphill L, Nachtigall L, Loeffler J, Swearingen B, Biller BM, Klibanski A (2010) Growth hormone deficiency after treatment of acromegaly: a randomized, placebo-controlled study of growth hormone replacement. J Clin Endocrinol Metab 95:567-577 